$0-113$

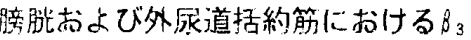
受容体の存在とその機能

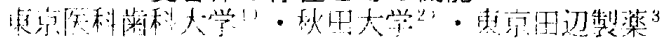

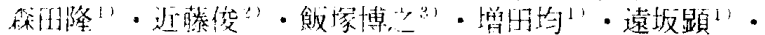

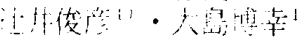

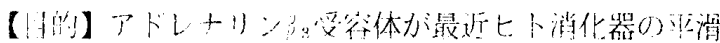

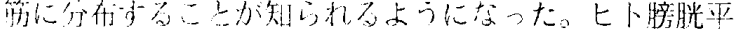

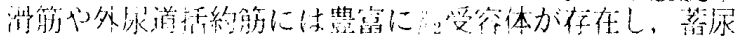

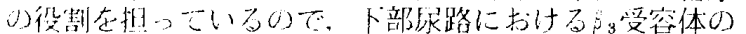

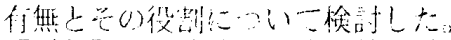

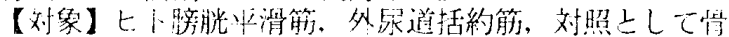

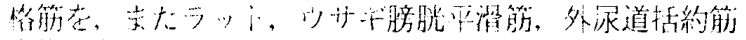
奋时いた。

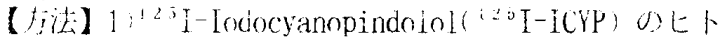

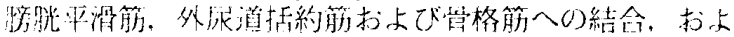

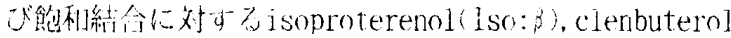

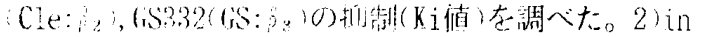

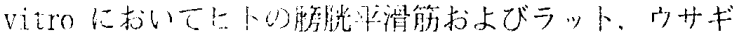

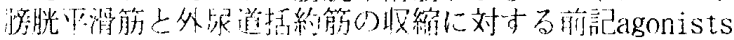

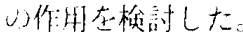

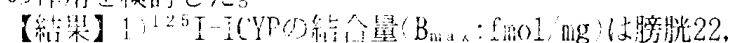

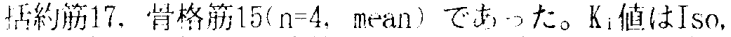

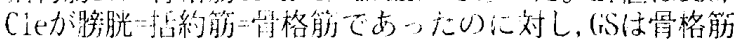

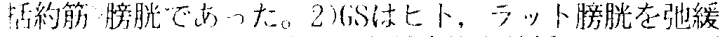

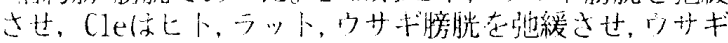
打約筋在收縮させた。

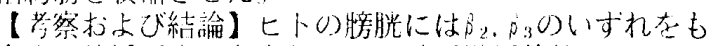

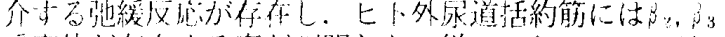

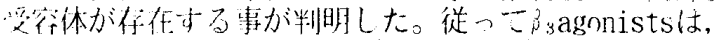

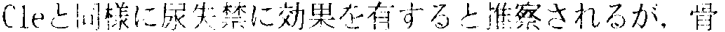

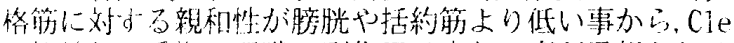

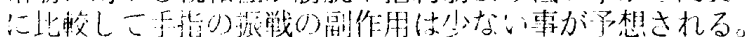

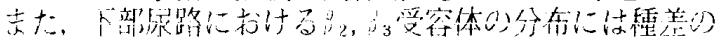

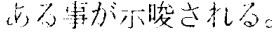

\section{O-115 ヒト排尿筋における $\beta_{3}$-アドレナリン受容体 機能の薬理学的および分子生物学的解明}

信州大学泌尿器科 ${ }^{1+}$. キッセイ薬品工業 (株) 創薬研究部 ${ }^{21}$ 井川清彦 ${ }^{1 !}$. 西澤 理 ${ }^{3} \cdot$ 山崎芳伸 $^{2 !}$. 武田裕夫 ${ }^{2}$. 早川

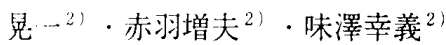

【目的】ヒト排尿筋には $\beta$-アドレナリン受容体（ $\beta$-AR） が存在し、膀胱の弛緩に関与している。近年、新たなサブ タイプである $\beta_{3}$-AR の存在がヒト脂肪細胞や消化管にお いて確認されたが、膀胱に扔ける $\beta_{3}$-ARに関する報告はは とんどない。今回我々はヒト膀胱に扮ける $\beta_{3}$-ARの存在お よび機能を検討した。【方法】臨床的に膀胱機能に異常を 認めない29症例から手術時に膀胱排录筋を採取し、縦走筋 方向の標本を作製した。マグヌス法により tonus レベルに 対する $\beta-\mathrm{AR}$ 刺激薬の作用および $\beta-\mathrm{AR}$ 遮断薬と isoproterenol の相互作用を検討した。また、 $\beta$-AR mRNA の発現をRT-PCR 法にて検討した。【結果】非選択的 $\beta$-AR 刺激薬 isoproterenol はヒト膀胱標本を濃度依存的に弛緩し、 その $\mathrm{EC}_{50}$ 值は $1.83 \mu \mathrm{M}$ であった。 $\beta_{3}$ - AR 刺激薬である CGP-12177A は濃度依存的な弛緩作用を示したが、 $\beta_{1}$-AR 刺激薬 dobutamine 抢よび $\beta_{2}$-AR 刺激薬 procaterol はほと九 ど弛緩作用を示さなかった。 $\beta_{1}-\mathrm{AR}$ 遮断薬 metoprolol 打よ び $\beta_{2}$-AR 遮断薬 ICI-118,551 は isoproterenol によるヒト膀 胱弛楥作用を抑制しなかったが、非選択的 $\beta$-AR 遮断薬 bupranolol は明かな拮抗作用を示した。さらに、ヒト膀胱に 抢いて $\beta_{1} 、 \beta_{2}$ 抢よび $\beta_{3}$-ARのいずれの mRNA も検出さ れた。【結論】ヒト膀胱には $\beta_{3}-\mathrm{AR}$ が存在し、 $\beta$-AR 作動

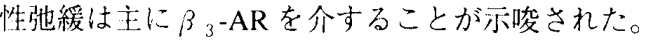

O-114 ウサギ、ラットおよびイヌ膀胱排尿筋における ß-アドレナリン受容体サブタイプ

キッセイ薬品工業 (株) 創薬研究部 ${ }^{1}$. 信州大学泌尿器科 ${ }^{2}$

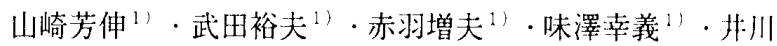
靖彦 ${ }^{2}$ ·西澤 理 ${ }^{2}$

【目的】哺乳類の膀胱には $\beta$-アドレナリン受容体（ $\beta-A R ）$ が存在し、排尿筋を弛緩させることが知られている。近华、 新たなサブタイプとして $\beta_{3}$-AR が同定されたが、膀胱にお ける $\beta_{3}$-AR の存在および機能に関する報告はほとんどな い。今回我々は選択的 $\beta-\mathrm{AR}$ 刺激薬抢よび遮断薬を用いて 各種動物膀胱の $\beta-\mathrm{AR}$ サブタイプについて薬理学的検討を 行った。【方法】ウサギ、ラットおよびイヌの膀胱体部よ り縦走筋方向の標本を作製した。マグヌス法により、tonus レベルに対する $\beta$-AR 刺激薬の作用および $\beta$ - AR 遮断薬と isoproterenolの相互作用を検討した。【結果】非選択的 $\beta$ AR 刺激薬 isoproterenol は3 種いずれの排尿筋も濃度依存的 に驰䋧させた。いずれの動物の排尿筋に対しても、 $\beta$ ，AR 刺激薬 dobutamine は弛緩作用を示さず、 isoproterenolによ る弛緩は $\beta_{1}$-AR 遮断薬 metoprolol によって拮抗されなか つた。 $\beta_{2}$-AR 刺激薬 procaterol はりサギおよびラット排尿 筋に対して低濃度から弛緩作用を示した。…方 $\beta_{3}$-AR 刺激 薬 CGP-12177A はイヌ排尿筋に対して最も強い池緩作用を 示した。 $\beta_{2}$-AR 遮断薬 ICI-118,551 は、ウサギおよびラッ 卜排㲾筋の isoproterenol 誘発弛緩反応を抑制したが、イ又 排尿筋では抑制しなかった。【結論】ウサギおよびラット 排尿筋は $\beta_{2}-\mathrm{AR}$ と $\beta_{3}$ - AR の両方を介して弛緩を示すのに 対し、イ又排尿筋は $\beta_{3}$-ARを介して弛緩することが明かと なった。

\section{O-116 ヒト膀腃排尿筋における}

$\beta$-adrenergic receptor subtype mRNAおよひ $\beta$-adrenergic receptor kinase mRNAの発現

一蕃尿における $\beta$-adrenergic receptorの役割と 脱感作機鹤の存在の可能性について-

\section{新舅大学泌尿器科}

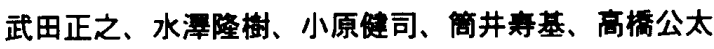

【目的】膀胱排尿筋は交感神経系 $\beta$-adrenergic

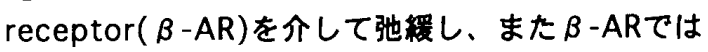
$\beta$-adrenergic receptor kinase( $\beta$-ARK)を介した 脱感作によって活性菜に対する感度か次第に低下する か、ヒト膀胱では明らかではない。そこでヒト膀胀排 尿筋における $\beta$-ARと $\beta$-ARKのmRNAの発現および $\beta$-ARを介した作用について検討した。【方法】術前 下部尿路閉塞のない患者から摘出した浐脱排尿筋を用 いた。Total RNAからcDNAを作䌘し、ヒト $\beta$ 1-AR、 $\beta 2-A R 、 \beta 3-A R お よ ひ ~ \beta-A R K 1 に$ 特異的なoligonucleotide primerを用いてPCR反応を行い、增幅さ れたDNA断片は電気泳動とSouthern hybridization

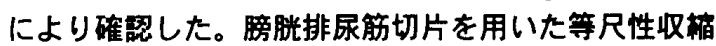
実験により、 $\beta$-ARを介した弛楥について娭討した。 【結果】 4 種類のmRNAの発現を㤎めた。Isoproterenol( $\beta-A R$ 非選択性活性菜) は、 $\beta$-AR選択性 拮抗菜の有無に関わらず、carbacolによる膀胀排尿筋 収耤を抑制した。【考繁】 $\beta$ 1-AR、 $\beta 2-A R 、 \beta 3-$ ARを介した排尿筋驰緩と、 $\beta$-ARKによる脱感作機粠 の存在の可能性が示唆された。 